\title{
Tüketici Davranışlarında Benlik Saygısı Kavramı: Bir Literatür Taraması
}

\author{
Alişan BALTACI ${ }^{1 *}$
}

Geliş Tarihi/Received: 11.05.2020

Kabul Tarihi/Accepted: 25.08.2020

Derleme Makalesi/Review Article

\section{ÖZET}

Tüketici davranışları literatüründe disiplinlerarası çalışmaların miktarı her geçen gün artmaktadır. Bunun temel sebebi konunun pek çok farklı havuzdan beslenmeye müsait oluşudur. Bu havuzlardan birisi de psikoloji literatürüdür. Psikoloji literatürünün konularından olan benlik saygısı kavramı, bireyin kendisine dair yapmış olduğu özdeğerlendirmenin öznel bir sonucudur. Sonucun yüksek veya düşük çıkması, bireyde farklı duygu durumlarına ve buna istinaden de farklı davranışlara sebep olabilmektedir. Bu çalışmanın amacı literatür taraması yöntemiyle, benlik saygısıyla ilgili olarak mevcut yerli ve uluslararası literatürde tüketici davranışlarına yönelik olarak yapılmış çalışmalara dair genel bir bilgi verilmesi, Türkçe araştırmalarda henüz değinilmemiş konuların aktarılması yoluyla yerli literatüre katkı sağlanması ve mevcut durumun bir resminin çekilebilmesidir.

Anahtar kelimeler: Benlik saygısı, Tüketici Davranışları, Literatür Taraması.

\section{Concept of Self-Esteem in Consumer Behavior: A Literature Review}

\begin{abstract}
Since the structure of the consumer behavior literature is suitable for multi-disciplinary studies the amount of such researches are increasing day by day. One of the most suitable literature for consumer behavior is the psychology where the concept of the self-esteem has been shaped. Self-esteem is the subjective result of a self-evaluation of a person. Each level of this evaluation causes a different emotional state which brings a different pattern of behavior. This study examines the concept of the self-esteem and its current intersection with the

\footnotetext{
${ }^{1}$ Dr. Öğr. Üyesi, Yüksek İhtisas Üniversitesi, Tıbbi Hizmetler ve Teknikler Bölümü, Orcid No: 0000-00023280-405X

* Sorumlu yazar/Corresponding author

E-mail/e-ileti: armada.alisan@gmail.com
} 
Baltacı, $A$.

consumer behavior literature theoretically. On the other hand, it's expected to make a contribution to the Turkish literature by touching on the unresearched issues from the global literature.

Keywords: Self-esteem, Consumer Behavior, Literature Review.

\section{GİRIŞ}

Benlik saygısı kavramı 1800'lü yılların sonundan beri insan davranışını açıklamaya çalışan araştırmalarda kendisine yer bulmaktadır. Özellikle 1965 yılında Rosenberg'in geliştirmiş olduğu ölçekle birlikte araştırmacılar tarafından daha da artan bir oranda irdelenmeye başlanmıştır. Tüketici davranışları ise İkinci Dünya Savaşı sonrası 1940'lı yılların ikinci yarısından itibaren pazarlama biliminin şemsiyesi altında sosyoloji, psikoloji, antropoloji, davranışsal iktisat ve iktisat gibi farklı sosyal disiplinlerden beslenerek gelişen bir alan olarak karşımıza çıkmaktadır. Dolayısı ile benlik saygısı kavramının tüketici davranışları-psikoloji etkileşimi kapsamında insan davranışlarını açıklayabilmek adına ele alınması şaşırtıcı değildir.

\section{BENLİK SAYGISI}

Benlik saygısı kavramının ilk olarak literatüre 1890 yılında James tarafından kazandırıldığı düşünülmektedir. Kendisi (James, 1890) benlik saygısını, bireyin arzuları ve başarıları arasında dalgalanan bir barometre olarak tanımlamaktadır.

Benlik saygısı, benlik kavramının değerlendirilmesinde kullanılan bir değerlendirme aracı olarak tanımlanmaktadır (Baumeister vd., 1998: 1252). Benlik saygısı ile kişiler öz değerlerini ölçmekte ve bunun sonucunda gelecekteki davranışlarını şekillendirmektedirler. Rosenberg'in 1965 yılında yaptı̆̆ çalışma ile temellerine oturan kavram çoğunlukla bireylerin kendileri ile ilgili olumlu değerlendirmeleri olarak tanımlanmaktadır. Literatür incelendiğinde benlik ile ilgili tanım genel itibari ile "benlik kendimizle ilgili ne düşündügümmüz; benlik saygısı ise benliğimizle ilgili yapmış olduğumuz olumlu ve olumsuz değerlendirmeler ve bu konuda ne hissettiğimizdir”. Literatürdeki kavramsallaştırma çalışmalarında benlik saygısı genel itibari ile üç konu etrafında şekillenmektedir:

- Boyutları: çok boyutlu olup olmadığının ortaya konulması,

- Tutarlılığı: kişiliğe dayalı sabit veya duruma göre değişken olup olmadığg,

- Benlik ile ilgili yapılan değerlendirmelerin bilişsel olup olmadığı. (Heatherton ve Wyland, 2003: 39) 
Geleneksel teorilere göre benlik saygısı tutarlı bir kişilik özelliğidir ve hiç değişmez yada çok az değişebilir (Heatherton ve Wyland, 2003: 39). Diğer taraftan bazı teoriler bu yaklaşımın ötesine geçmişlerdir. Bu teorilere göre benlik saygısı koşul ve durumlara bağlıdır. Ayrıca sosyal koşullarla da yakından ilgilidir ve diğer bireylerin değerlendirmeleri ile ruh hali de bunun üzerinde etkilidir (Kernis, 1993: 1192).

Uzun dönemli çalışmalar, araştırmacılara benlik saygısının daha dinamik olan doğasını keşfedebilme imkanı sağlamaktadır (Thewissen, vd., 2008: 43). Bunlara ek olarak bireylerin her zaman olumsuz duygulardan kaçınamayacağını, başarılarının bazı durumlarda dışsal etkenlere bağlı olduğunu, bu sebeple bireylerin benlik saygılarının zaman içerisinde tutarsızlık gösterebileceğini ifade eden araştırmalar da bulunmaktadır (Thewissen vd., 2008). Buradan hareketle benlik saygısının Maslow’un (1954) ihtiyaçlar hiyerarşisi piramidinde en yüksek olduğu nokta, kendini gerçekleştirme basamağıdır denilebilir (Maxwell ve Bachkirova, 2010: 17).

Gecas (1982) ve Cast ile Burke'e (2002) göre benlik saygısı iki boyut üzerine kavramsallaştırılabilir. Bunlardan birincisi yeterliliktir. Yeterlilik, bireyin kendi toplam beceri kapasitesini ve etkililiğini nasıl değerlendirdiği ile ilgilidir. İkinci boyut ise değere dayalı benlik saygısıdır. Değer kavramı burada bireyin kendisini ne kadar önemli/değerli algıladığı ile ilgilidir. Birlikte ele alındığında bu ikisi bireyin özdeğerlendirmesini şekillendirmektedir.

Benlik saygısının ölçülmesinde genel olarak:

- Bir davranışın sonucunda ortaya çıkan durum,

- Zararlı bir davranışa engel olan bişişsel bir tampon,

- Mevcut veya gelecekteki davranışı yönlendiren kişisel bir motivasyon konuları ele alınmaktadır. (Sages ve Grable, 2011: 1)

Cast ve Burke (2002) bu üç konunun yeterince sentezlenmediğini ileri sürmektedirler. Bu sebeple Stryker'ın 1980 yılında ortaya koyduğu kişilik teorisi çerçevesinde bu üç konuyu sentezleyen formal benlik teorisini (formal theory of self-esteem-TSE) geliştirmişlerdir. $\mathrm{Bu}$ teorinin varsayımına göre benlik saygısı çıktı, tampon/engel ve kendini motive edici özelliktedir.

Yapılan araştırmalara göre benlik saygısı düzeyi eşit iki kişiden birisi için durum oldukça uyumlu iken diğeri için bir ego enflasyonuna sebep olabilmektedir (ZeiglerHill ve 
Terry, 2007). Dolayısı ile benlik saygısı için standart bir gerçeklikten ziyade subjektif bir algıdır demek daha yerinde olacaktır (Baumeister vd., 2003: 1-2).

Stryker'a (1980) göre benlik; pek çok ayrı kimliği barındıran çok boyutlu bir oluşumdur. Her bir kimlik, bireyin topluma nasıl uyum sağlayacağını yansıtmaktadır. Daha geniş bir ifade ile bu çerçeve, benliği kimlik teorisi kapsamında ele almaktadır. Kimlik teorisinin temelinde bireyin özdoğrulama arayışları bulunmaktadır. Cast ve Burke (2002) formal benlik teorisini özdoğrulama üzerine inşa etmişlerdir. "Kimlik ile ilgili doğrulama süreci yeterlilik, değer ve artan benlik saygısı üretmektedir" demektedirler (Cast ve Burke, 2002). Özdoğrulama her ne kadar olumlu veya olumsuz sonuçlanabiliyor olsa da benlik saygısının şekillenmesinde önemli bir role sahiptir.

Bazı araştırmacılar benlik saygısını öz-değerden veya kendini kabullenmeden, özsaygıdan, liyakattan kaynaklanan genel bir hissiyat olarak tanımlamışlardır. Crocker ve Major (1989: 609) benlik saygısının salt benlik kavramının içerisinde geçen özgüven, özdeğerlendirme, kolektif benlik saygısı, ırsi benlik saygısı gibi kavramlarla ayrıștığını; genel benlik saygısının bireyin kendi özdeğer algısı ile ilişkili olduğunu ifade etmektedirler ve diğer kavramların az veya çok sosyal gruplar ile ele alınması gerektiğine işaret etmektedirler. Caprara vd. (2009: 277) 428 çift ikiz kardeş ile yaptığı çalışmada benlik saygısı için optimizm ve hayat tatmini ile birlikte genetik bir bileşene sahiptir demektedir. Ramsdal (2008: 337) ise benlik saygısının kendini sevmek ve öz-yeterlilik bağımsız değişkenlerinin bir sonucu olduğunu ifade etmektedir.

Zeigler-Hill ve Terry (2007) benlik saygısı kavramının yanlış değerlendirildiğini; bunun tutarlı ve tek düze bir yapı olarak ele alınmasının yanlış olduğunu iddia etmektedirler. Bu çıkarımlarının üzerine kırılgan benlik saygısı ile dengeli benlik saygısı kavramlarını ortaya koymuşlardır. Dengeli benlik saygısının daha sağlam bir yapı olduğunu; kırılgan benlik saygısının ise dış etkenler sebebi ile daha değişken bir yapı olduğunu ifade etmektedirler. Buradan hareketle kırılgan benlik saygısının olumsuz davranışların temelinde yatan sebeplerden birisi olduğunu ileri sürmektedirler. Aynı çalışmada mükemmeliyetçilik ile benlik saygısı arasında bir ilişki olduğunu ve mükemmeliyetçiliğin yeme bozukluğu, obsesif kompulsif kişilik bozukluğu, depresyon gibi bir takım olumsuz sonuçlara da sebep olduğunu ifade etmektedirler. Anoreksi, nevroz ve yeme bozukluklarının da benlik saygısına bağlı olduğunu ifade eden çalışmalar bulunmaktadır (Grabe ve Hyde, 2006; Meyers ve Biocca, 1992). 
ABD’de öğrenciler üzerinde Forsyth vd. (2007) tarafından yapılan araştırmalarda ise öğrencilerin benlik saygısı düzeyinin yüksek çıkmasına rağmen akademik başarılarının neden düşük olduğu sorgulanmıştır. Bu çalışmada başarısız öğrencilerden seçilen bir grubun benlik saygısı seviyelerini yükseltecek bazı yöntemler denenmiş, yapılan gözlemlerde benlik saygısı yükselen bu öğrencilerin akademik başarılarının daha da düştüğü gözlemlenmiştir. Dolayısıyla benlik saygısının yükselmesinin mesleki başarıya olumlu bir etki sağladığını ifade etmek mümkün değildir demektedirler.

Dweck (2008), Renaud ve McConnell (2007), Zeigler-Hill ve Terry (2007) yaptıkları çalışmalarda yüksek benlik saygısının, bireyin yaşadığı değişimlere daha hızlı adapte olmasına, hayata devam etmesine veya yeni bir yol bulmasına yardımcı olduğunu ifade etmektedirler.

Aşağıdaki özet tablo benlik saygısı kavramı ile ilgili kronolojik olarak araştırmacıların ortaya koymuş oldukları genel çerçevelere yönelik olarak Maxwell ve Bachkirova'dan (2010) uyarlanmıştır.

Tablo 1. Benlik saygısı literatürüne kronolojik bir bakış

\begin{tabular}{|c|c|c|}
\hline Teorisyen/Yll & $\begin{array}{l}\text { Kavramsal } \\
\text { Yaklaşım }\end{array}$ & $\begin{array}{c}\text { Potansiyel } \\
\text { Motive Edici }\end{array}$ \\
\hline $\begin{array}{c}\text { James, } \\
1890\end{array}$ & $\begin{array}{l}\text { Bireyin hayattaki başarılarının } \\
\text { başarısızlıklarına oranıdır }\end{array}$ & $\begin{array}{l}\text { Bireyin amaçlarına ulaşması, } \\
\text { yetkinliklerini arttırması }\end{array}$ \\
\hline $\begin{array}{l}\text { Cooley, 1909; } \\
\text { Mead, } 1913\end{array}$ & $\begin{array}{c}\text { Bireyin içsel ve sosyal hedeflerine } \\
\text { ulaşabilme derecesidir }\end{array}$ & $\begin{array}{l}\text { Bireyin benliğinin başkalarının } \\
\text { gözünde kabul görmesi }\end{array}$ \\
\hline $\begin{array}{l}\text { Rogers, 1951; } \\
\text { Maslow, 1954 }\end{array}$ & $\begin{array}{c}\text { Bireyin değerleri, ihtiyaçları ve } \\
\text { standartları ile uyumluluk derecesidir }\end{array}$ & $\begin{array}{l}\text { Benlik ve bireysel ihtiyaçlara } \\
\text { yönelik olarak ortaya çıan algı }\end{array}$ \\
\hline $\begin{array}{c}\text { Baumeister, } \\
\text { 1993-1999 }\end{array}$ & $\begin{array}{l}\text { Bireyin algıladığı benliğini muhafaza } \\
\text { etmesi veya onarması/yükseltmesidir }\end{array}$ & $\begin{array}{l}\text { Kendini geliştirme } \\
\text { ve öz tutarl1lık }\end{array}$ \\
\hline $\begin{array}{c}\text { Ryan ve } \\
\text { Warren Brown, } 2003\end{array}$ & $\begin{array}{l}\text { İç kaynaklardan bağımsız, } \\
\text { özgün benlik saygısı }\end{array}$ & $\begin{array}{l}\text { Amaçlar ve sebepler } \\
\text { benlikten önemlidir }\end{array}$ \\
\hline
\end{tabular}

Kaynak: Maxwell ve Bachkirova, 2010: 20 (Uyarlanmıştır)

Tabloya istinaden kavram 100 yılı aşkın yolculuğunda hayattaki başarılardan özgün ve bağımsız bir bilişsel olguya doğru evrilmiştir denilebilir.

\section{BENLİK SAYGISININ ÖLÇÜLMESİ}

Rosenberg (1965), benlik saygısının kendi içerisinde global ve spesifik bileşenlerine ayrılabileceğini iddia etmiş ve Rosenberg Benlik Saygısı Envanteri’ni (BSE-SEI) geliştirmişstir. Literatürdeki pek çok çalışmada da bu envanterden istifade edilmektedir. 
$\mathrm{Bu}$ envantere getirilen en önemli eleştrilerden birisi kişinin ruh haline göre farklı sonuçlar verebiliyor olmasıdır (Andrews ve Brown, 1993: 570). Bu sebeple genel bir durumu değil anlık bir durumu ölçtüğü yönünde eleştirilere maruz kalmaktadır. Bir diğer eleştiri ise yine Andrews ve Brown (1993) tarafından dile getirilen; içerisinde hem olumlu hem de olumsuz bireysel değerlendirme araçlarını barındırdığı, aslında bunların her birinin ayrı ayrı ele alınması gerektiğidir. Bu sebeple Smith vd. (2006) BSE'nin olumlu benlik değerlendirmelerinin varlığını/yokluğunu, kişinin o anki ruh haline göre ölçtüğünü ileri sürmektedir. Sonuç itibari ile BSE ve diğer benzer ölçekler, bireysel özbildirime bağlıdırlar ve benlik saygısını bilişsel bir süreç olarak ele almaktadırlar (Heatherton ve Wyland, 2003).

Benlik Saygısı Envanter'i Çuhadaroğlu tarafından 1986 yılında Türkçe’ye çevrilmiş ve literatürümüzde de yaygın kullanılan bir araç olmuştur. Yine 2010 yılında Tukuş tarafından Türkçeleştirilen ve Türkçe literatürde yaygın olarak kullanılan kısaltılmış ölçek formu da bulunmaktadır. Yapılan incelemede envanterin eğitim bilimleri, psikoloji ve tıp bilimleri alanında çalışma yapan Türk araştırmacılar tarafından sıklıkla kullanıldığı görülmektedir.

Rosenberg'in (1965) geliştirmiş olduğu ölçek her ne kadar literatürün en yaygın kullanılan ölçeği olsa da bunun dışında geliştirilmiş ölçekler de bulunmaktadır. Örneğin;

- Luthanen ve Crocker tarafindan 1992 yılında geliştirilen "Kolektif Benlik Saygısı Ölçeği” bireyin benlik saygısını, ait olduğu sosyal topluluk üzerinden yaptığı özdeğerlendirme ile ortaya koymaya çalışmaktadır.

- 1991 yılında Heatherton ve Polivy tarafından geliştirilen "Durumsal Benlik Saygısı Ölçeği” bireyin sahip olduğu sosyal, bilişsel ve fiziksel kaynaklarından tatmin olma derecesine göre benlik saygısı düzeyini ifade etmeye çalışmaktadır.

- Brumfitt ve Sheeran (1999) ise kelimelerle ölçüm yapılmasının mümkün olmadığ1 durumlarda kullanılabilmek üzere “Görsel Analog Benlik Saygısı Ölçeği”ni geliştirmişlerdir.

Sayılan ölçekler dışında da farklı amaçlarla geliştirilmiş ve yapı geçerliliğine sahip ölçekler bulunmakla beraber bunların yaygın kullanım alanı bulduklarını söylemek mümkün değildir.

\section{BENLİK SAYGISI VE TÜKETİCI DAVRANIŞLARI ÜZERINNE YAPILMIŞ ÇALIŞMALAR}

Yapılan incelemelerde benlik saygısı kavramının her ne kadar 1800'lü yılların sonunda tanımlandığı ve 1965 'teki Rosenberg'in çalışması ile literatürde daha fazla yer 
edinmeye başladığı görülse de tüketici davranışları alanında konuya olan ilginin 2000'li yıllardan itibaren ortaya çıktığını söylemek yerinde olacaktır. Bu bölümde konu ile ilgili küresel literatürde öne çıkan araştırmaların kapsam ve çıktıları ile yerli çalışmaların genel durumuna kronolojik olarak değinilecektir.

Dittmar ve Durry (2000) benlik saygısı (özellikle benlik imgesi) ile satın alma davranışı arasında doğrudan bir ilişki olduğunu ifade etmektedirler. Yaptıkları çalışmada satın almanın sadece benlik saygısını değil, aynı zamanda özgüveni de yükselttiğini tespit etmişlerdir.

Bizman ve Yinon, (2002) tüketicilerin markanın sahip olduğu prestij ile kendi kimlikleri arasında bir ilişki kurarak benlik saygısı düzeylerini arttırmak eğiliminde olduklarını söylemektedir.

Pazar kurtları; en uygun fiyatlı, kullanışlı ve kaliteli mal ve hizmetlere nerelerde ulaşılabileceğine dair diğer tüketicilere kullanışlı bilgiler veren kişiler olarak tanımlanabilir (Tayfun, 2015). Clark ve Goldsmith (2005) pazar kurtlarının psikolojik etkilerini inceledikleri çalışmada bu tip bireylerin yüksek benlik saygısına sahip olduklarını ve düşük benlik saygısına sahip bireyleri etkileyerek satın alma kararları üzerinde etkili olduklarını vurgulamaktadirlar.

Adkins ve Ozanne (2005) satın alma davranışının bireylerin kimlik inşasında ve yönetilmesinde başvurulan sosyal bir uygulama olduğunu, hatta günlük rutin alışverişlerde dahi bu davranışı gösterme şekli ile benlik saygısı ve itibar elde etme çabasında olduklarını vurgulamaktadirlar.

Park ve Roedder-John (2009) açık ve örtülü benlik saygısı üzerindeki uyuşmazlıkların materyalizm üzerindeki değişime nasıl etki edebileceğini araştırmış; örtülü ve açık benlik saygısı arasındaki fark arttıkça materyalizm eğiliminin de yükseldiğini tespit etmişlerdir.

Tüketicinin yükselen benlik saygısı sebebi ile yapacağı satın alma kararını en doğru şekilde gerçekleştireceğine dair inancı da yükselebilir. Bu durumda tüketicinin satın alma sürecinde bilmiş-ukala tavırlar sergilemesi de beklenebilir (Liu, 2010: 75).

Cunnigham ve Drake (2011) düşük benlik saygısına sahip bireylerin satın aldıkları ürünlerde narsistleri taklit ettiklerini ve prestij için satın alma davranışı sergilediklerini; yüksek benlik saygısına sahip tüketicilerin ise daha değer odaklı ve fonksiyonel ürünler tercih ettiklerini tespit etmişlerdir. 
Truong ve McColl (2011) bireyin kendini ödüllendirme davranışı olarak ortaya çıkan satın alma davranışının benlik saygısından kaynaklanan bir haz arayışı olduğunu ifade etmektedirler.

Sages ve Grable (2011) değer ve etkililik temelli benlik saygısı boyutları ile tüketicilerin finansal davranışları arasındaki ilişkiyi ele aldıkları çalışmalarında; benlik saygısının geçmiş davranışlar için bir çıktı, gelecekteki olumsuz davranışlar için bir engel ve gelecekteki olumlu davranışlar için de bir belirleyici olduğunu ifade etmektedirler. Yine aynı çalışmada eğitim seviyesinin yükselmesinin benlik saygısını arttırıcı bir etkiye sahip olduğu ifade edilmekte; bu sebeple de bireylerin daha fazla kredi kullanarak benlik saygılarını harcamaları ile belli bir seviyede tutmaya çalıştıkları; dolayısı ile borçlarını ödeyememe riski ile daha sık karşılaştıkları, borçları yüzünden emekli olabilecekken hala çalışmaya devam ettiklerine de dikkat çekilmektedir.

Lee ve Lin (2011) sağlı hizmetlerinde üretilen değer üzerine yapmış oldukları araştırmada genel hizmet yerine kişiye özel hizmet alan hastaların tedavi süresince benlik saygılarının yükseldiğini tespit etmişlerdir.

Konuyu benlik imgesi üzerinden değerlendiren çalışmalar da bulunmaktadır. Benlik imgesi; bireyin kendisini bir nesne olarak tanımladığında başvurduğu duygu ve düşüncelerin bir toplamıdır (Resermberg, 1979). Souiden vd. (2011) Kanadalı ve Tunuslu tüketiciler üzerine yaptıkları kültürler arası araştırmada her iki ülkenin de tüketicilerinin benlik-imgeleri vasıtası ile sosyal statülerini göstermeye çalıştıklarını ve bunun benlik saygılarını arttırdığını; bu durumun zaman zaman tüketicileri gösterişçi tüketime yönlendirdiğini ifade etmektedirler. Bu tip davranışın seviyesi, bireyin benlik-imgesi ile markanın öz-imgesinin örtüştüğü oranda artmaktadır. Özellikle Tunuslu katılımcıların sosyal statülerinin benlik saygıları üzerinde oldukça önemli bir etkiye sahip olduğu bulgular arasındadır. Tunus kültüründe, bireyin gösterişçi tüketim davranışı göstermesi üzerinde benlik saygısının doğrudan olmayan bir etkisi olduğu da ifade edilmektedir. Yine Tunuslu tüketicilerden benlik saygısı seviyesi düşük olanların daha yüksek marka değeri olan ürünlere yöneldiği de araştırmanın sonuçlarındandır. Diğer taraftan Kanadalı tüketiciler için gösterişçi tüketim davranışında, benlik saygısının anlamlı bir etkisine rastlanmamıştır.

Sayılanlara ek olarak literatürde benlik saygısı düzeyi ile mutluluk düzeyi arasında olumlu yönde bir ilişki olduğunu ifade eden çalışmalar da bulunmaktadır (DeNeve ve Cooper, 1998; Lyubomirsky ve Lepper, 2006). Gösterişçi tüketimin bireyin mutluluk düzeyini ve dolayısı ile benlik saygısını tüketimden algıladığı tatmin sebebi yükselttiği söylenmektedir 
(Truong ve McColl, 2011). Buna benzer şekilde sosyal medya kullanımının da benlik saygısını ve dolayısı ile gösterişçi tüketimi arttırdığını ifade eden çalışmalar bulunmaktadır (Troung ve McColl 2011; Lewis ve Moital, 2016).

Ulusal Tez Merkezi'nde kayıtlı tezler üzerinden 10.05.2020 tarihinde yapılan taramada tüketici davranışları temelli olarak benlik saygısı ile ilintili yazılmış dört adet tez çalışması olduğu tespit edilmiştir. Bu tezlere dair bilgi aşağıda paylaşılmıştır.

Tablo 2. Türkiye'de benlik saygısı ve tüketici davranışları ile ilgili yazılmış tezler

\begin{tabular}{|c|c|c|c|}
\hline Yılı & $\begin{array}{c}\text { Diploma } \\
\text { Düzeyi }\end{array}$ & Yazar & Tez Adı \\
\hline 2011 & $\begin{array}{c}\text { Yüksek } \\
\text { Lisans }\end{array}$ & $\begin{array}{c}\text { İbrahim } \\
\text { Bozacı }\end{array}$ & $\begin{array}{r}\text { Şikâyet yönetim sürecinde müşterinin firmaya } \\
\text { şikâyet etme eğilimini etkileyen faktörler üzerine } \\
\text { uygulamalı bir çalışma }\end{array}$ \\
\hline 2015 & Doktora & $\begin{array}{c}\text { Filiz } \\
\text { Eroğlu }\end{array}$ & $\begin{array}{c}\text { Kompulsif satın alma eğiliminde kişisel faktörlerin, } \\
\text { postmodern tüketim şekillerinin ve bir pazarlama } \\
\text { çabası olarak reklamın rolü }\end{array}$ \\
\hline 2018 & $\begin{array}{c}\text { Yüksek } \\
\text { Lisans }\end{array}$ & $\begin{array}{c}\text { Fulya } \\
\text { Midilli }\end{array}$ & $\begin{array}{c}\text { Türk tüketicilerin yeşil ürünlere karşı tutumu ve } \\
\text { satın alma niyetleri üzerine bir keşif çalışması }\end{array}$ \\
\hline 2019 & $\begin{array}{c}\text { Yüksek } \\
\text { Lisans }\end{array}$ & $\begin{array}{c}\text { Begüm } \\
\text { Çeliktutan }\end{array}$ & $\begin{array}{c}\text { Benlik ile gelişmeleri kaçırma korkusunun } \\
\text { pazarlamadaki ilişkisi }\end{array}$ \\
\hline
\end{tabular}

DergiPark üzerinden yapılan taramada ise 10.05.2020 tarihi itibari ile benlik saygısı özelinde 396 makale listelenmekte olup bunların büyük bölümü psikoloji ve eğitim bilimleri alanlarında yazılmıştır. $\mathrm{Bu}$ makaleler arasında tüketici davranışları üzerine yazılmış olup doktora veya yüksek lisans tezinden türetilmemiş dört makale tespit edilmiştir. Bu makaleler Tablo-3'te kronolojik sıra ile gösterilmektedir.

Tablo 3. Türkiye'de Benlik Saygısı ve Tüketici Davranışları ile İlgili Yazılmış Tezler Makaleler

\begin{tabular}{|c|c|c|c|}
\hline Yılı & Dergi & Yazar & Makale Adı \\
\hline 2009 & $\begin{array}{c}\text { Gazi Üniversitesi İ̈BF } \\
\text { Dergisi }\end{array}$ & $\begin{array}{c}\text { Can Armutlu; } \\
\text { M. Mithat } \\
\text { Üner }\end{array}$ & $\begin{array}{c}\text { Benlik İmajı Uyumu, Tüketici Tatmini ve Marka } \\
\text { Sadakati İlişkisi Üzerine Görgül Bir Araştırma }\end{array}$ \\
\hline 2016 & $\begin{array}{c}\text { Süleyman Demirel } \\
\text { Üniversitesi SBE } \\
\text { Dergisi }\end{array}$ & $\begin{array}{c}\text { Aysel Erciş; } \\
\text { Güzin Kotan; } \\
\text { Bahar Türk }\end{array}$ & Ölüm Kaygısının Tüketici Tutumları Üzerindeki \\
Etkileri
\end{tabular}




\section{SONUÇ VE DEĞERLENDİRME}

Tüketicilerin ihtiyaç ve isteklerinin tamamının nesnel değerlendirme süzgeçlerinden geçerek satın alma kararına dönüştüğünü söylemek mümkün değildir. Dolayısı ile tüketici davranışlarını anlayabilmek ve anlamlandırabilmek için tüketicinin öznel değerlendirme süreçlerine de odaklanmak gerekmektedir. Benlik saygısı kavramı da bu noktada önemli bir öznel değerlendirme süreci olarak karşımıza çıkmaktadır.

Benlik saygısı bireyin kendisini diğer bireyler, toplum, ait olduğu topluluk, hayattan beklentilerine ulaşabilme derecesi gibi pek çok farklı değişken üzerinden bilişsel olarak değerlendirdiği ve sonucunda ulaşmak istediği ideale yaklaştığı ölçüde başarılı ve tatmin olmuş hissettiği öznel bir süreçtir. Sürecin sonunda birey, eğer arada olumsuz bir fark varsa bu farkı giderebilmek adına eyleme geçecektir. Bahsi geçen eylemler arasında tüketim de bulunmaktadır.

Literatürün bu noktada özellikle düşük benlik saygısının sonuçlarına odaklandığını söylemek de mümkündür. Az miktarda çalışmada ise yükselen benlik saygısının etkilerine değinilmektedir. Dolayısı ile yükselen benlik saygısının bireyin tüketim çıktılarına dair çalışmalarının literatüre katkı sağlayacağını söylemek yerinde olacaktır. Ayrıca kavramın marka bağımlılığı, marka sadakati, yeşil tüketim, gösterişçi tüketim, impulsif/kompulsif satın alma, şikayet davranışı vb. pek çok farklı tüketim davranışı ile beraber ele alınabileceği de değerlendirilmektedir.

Yine yapılan taramalardan anlaşıldığı kadarı ile Rosenberg Benlik Saygısı Ölçeği'nin oldukça baskın bir konumda olduğu ve diğer ölçeklerin yeteri kadar ilgi görmediği değerlendirilmektedir. Farklı ölçeklerle yapılacak çalışmaların tüketici davranışının henüz irdelenmemiş alanlarını da gözler önüne sereceği düşünülmektedir.

Nihayetinde benlik saygısı kavramının tüketici davranışları literatüründe açıklayabileceği ve aydınlatabileceği oldukça geniş bir alan bulunmaktadır. Bu alanlar aydınlatıldıkça tüketicilerin tutum, davranış, karar ve tercihlerinin altında yatan sebepler de daha iyi anlaşılabilecektir.

\section{KAYNAKÇA}

Adkins, N.R. ve Ozanne, J.L. (2005). The Low Literate Customer. Journal of Consumer Research, Vol.32, June 2005, 93-105 .

Andrews, B. ve Brown, G.W. (1993).Self-esteem and vulnerability to depression: The concurrent validity of interview and questionnaire measures. Journal of Abnormal Psychology, Vol 102(4), Nov 1993, 565-572. 
Armutlu, C. ve Üner, M.M. (2009). Benlik imajı uyumu, tüketici tatmini ve marka sadakati ilişkisi üzerine görgül bir araştırma. Gazi Üniversitesi İIBF Dergisi, 11(3), 1-26

Asıl, S. (2017). Tüketimde benlik algısı: sosyal medya hesaplarında tüketici olmak. ÇOMÜ Uluslararası Sosyal Bilimler Dergisi, 2(3), 1-22.

Baumeister, R. F., Campbell, J. D., Krueger, J. K., ve Vohs, K. D. (2003). Does high selfesteem cause better performance, interpersonal success, happiness, or healthier lifestyles? Psychological Science in the Public Interest. Vol:4, Issue:1, 1-44.

Baumeister, R.E., Bratslavsky, E., Muraven, M., ve Tice, M. (1998). Ego Depletion: Is the active self a limited resource?. Journal of Personality and Social Psychology, June. 1998, 74(5), 1252-65.

Bizman, A. ve Yinon, Y. (2002). Engaging in distancing tactics among sport fans: effects on self-esteem and emotional responses. The Journal of Social Psychology. 142 (3), 381-392.

Bozacı, İ. (2011). Şikâyet yönetim sürecinde müşterinin firmaya şikâyet etme eğilimini etkileyen faktörler üzerine uygulamalı bir çalışma. Yayınlanmamış Yüksek Lisans Tezi.

Brumfitt, S. ve Sheeran, P. (1999). The development and validation of the visual analogue self-esteem scale (VASES)1. The British Journal of Clinical Psychology / the British Psychological Society. 38 ( Pt 4), 387-400

Caprara, G., Fagnani, C., Alessandri, G., Steca, P., Gigantesco, A., Sforza, L., Stazi, M.A. (2009). Human optimal functioning: the genetics of positive orientation towards self, life, and the future. Behavior Genetics. 39, 277-284.

Cast, A.D., ve Burke, P.J. (2002). A theory of self-esteem. Social Forces, 2002; 80 (3), 10411068.

Clark, R.A. ve Goldsmith, R.E. (2005). Market mavens: psychological influences. Psychology and Marketing, Vol. 22(4), (April 2005), 289-312.

Crocker, J., ve Major, B. (1989). Social stigma and self-esteem: The self-protective properties of stigma. Psychological Review, 96, 608-630

Cunningham, M.A., Drake,K. ve Drake, P. (2011). Because I'm worth it (and you're not): Separating the effects of narcissism and self-esteem on prestige purchases, Advances in Consumer Research, Volume 38, 896-897.

Çeliktutan, B. (2019). Benlik ile gelişmeleri kaçırma korkusunun pazarlamadaki ilişkisi. Yayınlanmamış Yüksek Lisans Tezi.

Çuhadaroğlu, F. (1986). Adölesanlarda benlik saygısı. Yayınlanmamış Uzmanlık Tezi. Hacettepe Üniversitesi, Tıp Fakültesi, Psikiyatri ABD, Ankara.

Deneve, K. M. ve Cooper, H. (1998). The happy personality: a metaanalysis of 137 personality traits and subjective well-being. Psychological Bulletin, 124, 197-229.

Devrani, T.K. (2018). Durumsal benlik saygısının reklam izleme ile kompulsif satın alma ilişkisindeki düzenleyici etkisi. Sosyal Araştırmalar ve Davranış Bilimleri Dergisi, Cilt 4, Say15, 118-133.

Dittmar, H. ve Drury, J. (2000). Self-image is it in the bag? A qualitative comparison between "ordinary" and "excessive" consumers. Journal of Economic Psychology, vol. 21, $109-142$.

Dweck, C.S. (2008). Can personality be changed? The role of beliefs in personality and change. Current Directions in Psychological Science, 17, 391-394. 
Erciş, A., Kotan, G. ve Türk, B. (2016). Ölüm kaygısının tüketici tutumları üzerindeki etkileri. Süleyman Demirel Üniversitesi SBE Dergisi, 2016/1 Sayı 23, 107-134.

Eroğlu, F. (2015). Kompulsif satın alma eğiliminde kişisel faktörlerin, postmodern tüketim şekillerinin ve bir pazarlama çabası olarak reklamın rolü. Yayınlanmamış Doktora Tezi.

Forsyth, D.R., Lawrence, N.K., Burnette, J.L., ve Baumeister, R.F. (2007). Attempting to improve the academic performance of struggling college students by bolstering their selfesteem: An intervention that backfired. Journal of Social and Clinical Psychology, 26, 447459.

Gecas, V. (1982). The self-concept. Annual Review of Sociology, 8, 1-33.

Grabe, S. ve Hyde, J. (2006). Ethnicity and body dissatisfaction among women in the United States: A meta-analysis. Psychological Bulletin, 132, 622-640

Heatherton, T.F. ve Polivy, J. (1991). Development and validation of a scale for measuring state self-esteem. Journal of Personality and Social Psychology, 60(6), 895-910.

Heatherton, T.F., ve Wyland, C.L. (2003). Why do people have self-esteem?. Psychological Inquiry, 14(1), 38-41

James, J. (1890). Principles of psychology. New York: Holt

Kernis, M.H., Cornell, D.P., Sun, C.R., Berry, A., Harlow, T., ve Bach, J.S. (1993). There's more to self-esteem than whether it is high or low: The importance of stability of self-esteem. Journal of Personality and Social Psychology, 65, 1190-1204.

Lee, W.I. ve Lin C.H. (2011). Consumer hierarchical value map modeling in the healthcare service industry. African Journal of Business Management, Vol. 5(3), 722-736

Lewis, A. ve Moital, M. (2016). Young professionals' conspicuous consumption of clothing. Journal of Fashion Marketing and Management. 20 (2), 138-156.

Liu. Y.J. (2010). A conceptual model of consumer sophistication. Innovative Marketing, 6(3), $72-77$

Luhtanen, R. ve Crocker, J. (1992). A collective self-esteem scale: self-evaluation of one's social identity. Personality and Social Psychology Bulletin, 18(3), 302-318.

Lyubomirsky, S. ve Lepper, H. S. (2006). What are the differences between happiness and self-esteem?. Social Indicators Research, 78, 363-404.

Maxwell, A. ve Bachkirova, T. (2010). Applying psychological theories of self-esteem in coaching practice. International Coaching Psychology Review, 5(1), 16-26.

Meyers, P.N. ve Biocca, F.A. (1992). The elastic body image: The effect of television advertising and programming on body image distortions in young women. Journal of Communications, 42 (September), 108-33.

Midilli, F. (2018). Türk tüketicilerin yeşil ürünlere karşı tutumu ve satın alma niyetleri üzerine bir keşif çalışması. Yayınlanmamış Yüksek Lisans Tezi.

Park, J.K. ve Roedder-John, D. (2009). More than meets the eye: the influence of implicit self-esteem on materialism. Advances in Consumer Research. Volume 36, 537-538.

Ramsdal, G.H. (2008). Differential relations between two dimensions of selfesteem and the big five?. Scandinavian Journal of Psychology, 49, 333-338. 
Renaud, J. M., ve McConnell, A. R. (2007). Wanting to be better but thinking you can't: Implicit theories of personality moderate the impact of self-discrepancies on selfesteem. Self and Identity, 6, 41-50.

Resenberg, M. (1979). Conceiving the Self. Basic Books. New York.

Rosenberg, M. (19659. Society and the adolescent self-image. Princeton, NJ: Princeton University Press.

Sages R.A., Grable J.E. (2011). A Test of the Theory of Self-Esteem: A Consumer Behavior Perspective. American Council on Consumer Interests. Washington, DC, 1-10.

Smith, B., Fowler, D.G., Freeman, D., Bebbington, P., Bashforth, H., Garety, P., Dunn. G. ve Kuipers, E. (2006). Emotion and psychosis: links between depression, self-esteem, negative schematic beliefs and delusions and hallucinations. Schizophrenia Research. 2006/Sep; 86(13), 181-188.

Souiden, N., M'Saad, B., ve Pons, F. (2011). A cross-cultural analysis of consumers' conspicuous consumption of branded fashion accessories. Journal of International Consumer Marketing, 23(5), 329-343.

Stryker, S. (1980). Symbolic Interactionism: A Social Structural Version. Menlo Park, CA: Benjamin/Cummings.

Tayfun, N.Ö. (2015). Pazar kurdu tüketicilerin demografik özelliklerinin belirlenmesine yönelik uygulama. KMÜ Sosyal ve Ekonomik Araştırmalar Dergisi, 17 (29), 17-22.

Thewissen, V., Bentall, R.P., Lecomte, T., van Os, J., ve Myin-Germeys I. (2008). Fluctuations in self-esteem and paranoia in the context of daily life. Journal of Abnormal Psychology, 117 (1), 43.

Truong, Y. ve McColl, R. (2011). Intrinsic motivations, self-esteem, and luxury goods consumption. Journal of Retailing and Consumer Services, 18(6), 555-561.

Tukuş, L. (2010). Benlik saygısı değerlendirme ölçeği-kısa formu türkçe güvenilirlik ve geçerlilik çalışması. Yayımlanmamış Tıpta Uzmanlık Tezi. Kocaeli Üniversitesi/Tıp Fakültesi, Kocaeli.

Zeigler-Hill, V., ve Terry, C. (2007). Perfectionism and explicit self-esteem: The moderating role of implicit self-esteem. Self and Identity, 6, 137-153. 